\title{
Evaluation of Drought Tolerant Maize Varieties under Drought and Rain-Fed Conditions: A Rainforest Location
}

\author{
Abimbola Oluwaranti ${ }^{1} \&$ Oluwatosin Temilade Ajani ${ }^{2}$ \\ ${ }^{1}$ Department of Crop production and Protection, Obafemi Awolowo University, Ile-Ife, Osun State, Nigeria \\ ${ }^{2}$ Institute of Ecology and Environmental Studies, Obafemi Awolowo University, Ile-Ife, Osun State, Nigeria \\ Correspondence: Abimbola Oluwaranti, Department of Crop Production and Protection, Obafemi Awolowo \\ University, Ile-Ife, Osun State, Nigeria. Tel: 234-806-783-0144. E-mail: boluwaranti@yahoo.com
}

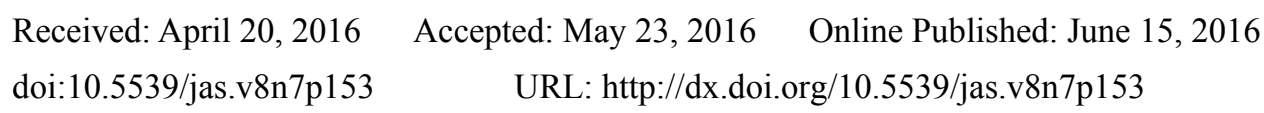

\begin{abstract}
Newly developed drought tolerant maize (Zea mays L.) varieties have been hypothesized to be of different genetic make-ups, hence this study was conducted to evaluate drought-tolerant maize varieties under drought and rain-fed conditions, identify the highest yielding varieties and determine the relationship between agronomic traits and varieties' yield under these conditions in a rainforest location. Nine drought tolerant varieties of maize and a local check were evaluated during the early part of the early cropping season (March) (Drought) as well as the actual early cropping season (May-June) (Rain-fed) of 2015 at the Teaching and Research Farm (T\&RF) of Obafemi Awolowo University, Ile-Ife $\left(7^{\circ} 28^{\prime} \mathrm{N}, 4^{\circ} 33^{\prime} \mathrm{E}\right.$ and $244 \mathrm{~m}$ above sea level). There were significant differences among the two environments for all the traits measured. The performance of the drought tolerant maize varieties is better under the rain-fed condition. The yield performance of all varieties are not significantly different from each other (1.36 tons/ha to 2.75 tons/ha) under drought except EVDT-W $2000 \mathrm{STR}_{0}$ (1.10 tons/ha). All the varieties evaluated under rain-fed condition produce higher grain yield (2-44 tons/ha-3.69 tons/ha) which are not significantly different each other. All the yield components except ear height and length had a strong positive relationship with grain yield under drought while only ear number and weight had relationship with yield under rain-fed condition. In conclusion, among the drought tolerant maize varieties, EVDT-W 2000 STR $C_{0}$ need further improvements to drought. Furthermore, ear weight can be used to select parents for the development of drought tolerant maize varieties in this agro-ecology.
\end{abstract}

Keywords: drought, maize, performance, rain-fed, tolerance

\section{Introduction}

\subsection{Maize Production and Uses}

Maize (Zea mays L.) is a C4 plant with specialized anatomical and biochemical features for a high photosynthetic efficiency. The crop is grown in climates ranging from temperate to tropical environment during the period when mean daily temperatures are above $15^{\circ} \mathrm{C}$ and are frost-free. Adaptability of varieties to different climates varies widely. Successful cultivation markedly depends on the right choice of varieties whose length of growing period matches the length of growing season and its purpose. FAOSTAT (2012) ranked Nigeria among the highest producers of maize in Africa, this is partly because maize is highly adapted to all the agro-climatic conditions in the country and a large production area devoted to the production. Maize grain has a variety of uses such as for human consumption, livestock feed and ethanol production (Milander, 2015). Maize is a staple food for more than 300 million people in Sub-Saharan Africa and a number of countries in these geographic regions. However, drought occurred in the same season, creating regional food shortages that cannot easily be alleviated by cross-border trade. Production of maize, for instance, in Southern Africa fluctuated from 12.5 million tons in 1992 (which was a drought year) to 23.5 million tons in 1993 (Edmeades, 2008).

\subsection{Maize Production Constraints}

Food productivity is decreasing due to detrimental effects of various biotic and abiotic stresses; therefore minimizing these losses is a major area of concern to ensure food security under changing climate. Environmental abiotic stresses, such as drought, extreme temperature, cold, heavy metals, or high salinity, severely impair plant growth and productivity worldwide. Drought, being the most important environmental stress, severely impairs 
plant growth and development, limits plant production and the performance of crop plants, more than any other environmental factors (Shao et al., 2009). Many of these environmental factors reduce the production of maize in the West and Central Africa (WCA) and more especially in Nigeria. Recurrent drought stress accounts for frequent food shortages in the WCA sub-region (Badu-Apraku et al., 2010) about $15 \%$ of total production is lost to recurrent drought. Similarly, recurrent drought has been reported as the most severe abiotic constraint in the WCA (Edmeades et al., 1997). Highest yield loss in maize occurs when the drought occurrence coincides with flowering and grain filling periods. Fakorede and Akinyemiju, 2003 identified rainfall as the primary environmental factor determining when to plant maize in the rainforest. They obtained historical records of climatic data that have been kept at the Teaching and Research Farm (TRF) of Obafemi Awolowo University, Ile-Ife, a typical rainforest location for about 30 years and analysed the data collected from 1975 to 2000 to determine the trends in climatic change, if any, and relate this to maize production at Ile-Ife. They found that over the years, rainfall was characterized by false starts and this showed a tendency to increase in the later than earlier years. The combination of reduced rainfall and false starts of the rainy season provides an explanation for increased drought probability in March, April and May observed at this location in recent years. The data failed to support the popular belief that delayed onset of the rainy season would be compensated for by delayed recession of the rains towards the end of the year. Apart from terminal drought, erratic rainfall pattern in Nigeria's SGS which often result in unpredictable mid-season drought, causes reduction in grain yield (Kim, 1997). Ashley (1999) reported that periodic drought caused by irregular rainfall, accentuated by low water holding capacity of tropical soils, as well as poor cultural practices and lack of appropriate varieties used by farmers, often cause maize crop losses. Plant experiences drought stress either when the water supply to roots becomes difficult to access or when the transpiration rate becomes very high. Available water resources for successful crop production have been decreasing in recent years. Furthermore, in view of various climatic change models, scientists suggested that in many regions of world, crop losses due to increasing water shortage will further aggravate its impacts. The susceptibility of plants to drought stress varies in dependence of stress degree, different accompanying stress factors, plant species, and their developmental stages (Demirevska et al., 2009).

\subsection{Improvement of Maize Production under Drought}

Several methods have been suggested to improve maize production under drought condition; they include the use of hydromorphic soil, use of irrigation and other cultural practices. However, genetic improvement has been identified as the most sustainable method of improving maize production under drought stress (Edmeades et al., 2004). The use of genetics to improve drought tolerance in maize and to provide yield stability is an important part of the solution to an increased global maize production. Edmeades et al. (2004) reported that genetic interventions are likely to close up to $30 \%$ of the gap between potential maize yield and realized yield. The International Institute of Tropical Agriculture (IITA) in collaboration with the Drought Tolerant Maize for Africa (DTMA) have developed several drought tolerant inbred lines, hybrids, synthetic and open pollinated maize varieties.

\subsection{Statement of Research Problem, Hypothesis and Objectives}

These newly developed drought tolerant maize varieties have been hypothesized to be of different genetic make-ups. However, some of these newly developed drought-tolerant maize varieties have not been evaluated under the marginal rainfall condition of the early part of the early cropping season of the rainforest agro-ecology, hence this study. Therefore the objectives of the study are to:

a) Evaluate drought-tolerant maize varieties under the marginal rainfall (drought) and rain-fed conditions;

b) Identify the drought-tolerant maize varieties with high yield under the two conditions; and,

c) Determine the relationship between the agronomic traits and grain yield of these drought-tolerant maize varieties.

\section{Materials and Methods}

\subsection{Experimental Materials}

Ten maize varieties comprising of nine drought-tolerant maize varieties obtained from Maize breeding program of International Institute of Tropical Agriculture (IITA), Ibadan, Nigeria and one local check variety from the Teaching and Research Farm, Obafemi Awolowo University (OAU), Ile-Ife were used for the study (Table 1). 
Table 1. Names and characters of the nine drought tolerant maize varieties and one local check evaluated in this study

\begin{tabular}{|c|c|c|}
\hline S/NO & Variety & Characters \\
\hline 1 & 2004 TZE-WDT STR $\mathrm{C}_{4}$ & Early, white, drought and striga tolerant \\
\hline 2 & EVDT-W 2000 STR C $_{0}$ & Early, white, drought and striga tolerant \\
\hline 3 & 2013 DTE STR-Y Syn & Early, yellow, drought and striga tolerant \\
\hline 4 & DT-Y STR Synthetic & Early, yellow, drought and striga tolerant \\
\hline 5 & 2009 TZE-WDT STR & Early, white drought and striga tolerant \\
\hline 6 & 2008 DTMA-Y STR & Early, yellow, drought and striga tolerant \\
\hline 7 & 2012 TZE-WDT C STR C $_{5}$ & Early, white, drought and striga tolerant \\
\hline 8 & 2014 TZE-WDT STR & Early, white, drought and striga tolerant \\
\hline 9 & 2011 TZE-Y DT STR & Early, yellow, drought and striga tolerant \\
\hline 10 & Obatanpa (Local Check) & Intermediate, white, quality protein maize \\
\hline
\end{tabular}

\subsection{Experiment's Location and Design}

The field experiment was carried out at the Teaching and Research Farm, Obafemi Awolowo University (OAU), Ile-Ife, Osun State, Nigeria. The research farm is located on latitude $07^{\circ} 33^{\prime} \mathrm{N}$ and longitude $04^{\circ} 33^{\prime} \mathrm{E}$. The ten varieties were planted just at the beginning of the early cropping seasons (March) which is normally characterized with drought condition and the peak of early cropping season (June) which is the normal rain-fed condition of year 2015. The experiment was laid out in a Randomized Complete Block Design (RCBD) consisting of ten maize varieties as treatments. Each treatment was replicated three times to give a total of thirty plots.

\subsection{Agronomic Practices}

The maize seeds were planted three seeds per hill and the plants were thinned to two at the three-leaf stage with a spacing of $75 \mathrm{~cm}$ between rows and $50 \mathrm{~cm}$ within row resulting into 53,333 plants/ha. Weeds were controlled with primextra, a pre-emergence herbicide which contained atrazine (2-chloro-4-(ethyl amino)-6isopropylamino-s-triazine) and alachlor (N-(1-methyl-2-methoxy-ethyl)-2-ethyl-8-methyl-chloroacetanilide) as active ingredients. The herbicide was applied one day after planting at the rate of 5 litres/ha. Weeds were also controlled by hand weeding as necessary after the crop had established.

Fertilizer NPK was applied at a total rate of $60 \mathrm{~kg} \mathrm{~N}, 30 \mathrm{~kg} \mathrm{P}_{2} \mathrm{O}_{5}$ and $30 \mathrm{~kg} \mathrm{~K} 2 \mathrm{O} / \mathrm{ha}$ in two splits; first at three weeks after planting and finally at five weeks after planting.

\subsection{Data Collection}

\subsubsection{Emergence Traits}

Emergence count of the maize plants was done at 5, 7 and 9 days after planting (DAP). The total number of seedlings in a plot on the $9^{\text {th }}$ DAP was expressed as a percentage of seeds planted to obtain emergence percent $(\mathrm{E} \%)$; that is:

$$
\mathrm{E} \%=\frac{\text { Seedling emerged } 9 \text { DAP }}{\text { Number of seeds planted }} \times 100
$$

\subsubsection{Growth Traits}

Plant and ear heights: The distance from the soil surface to the nodes bearing the flag leaf and the top ear were obtained for 5 random plants in a plot and their means were expressed as plant height (PHT) and ear height (EHT), respectively.

\subsubsection{Grain Yield and Yield Components}

Number and weight of ears, Moisture Content (MC) at harvest per plot, Kernel Row Number (KRN), Ear Length (EL), Ear Diameter (ED) were also obtained from five ears per plot.

\subsubsection{Climatic Data}

Monthly climatic data on minimum and maiximum temperature, rainfall, sunshine hour and evapotranspiration were obtained from the Automatic Weather Station located at the Teaching and Research Farm, OAU, Ile-Ife (Table 2). 
Table 2. Monthly climatic data of the experimental site for cropping seasons of 2015

\begin{tabular}{lllllll}
\hline & $\mathbf{T}_{\min }$ & $\mathbf{T}_{\mathbf{m a x}}$ & $\mathbf{T}_{\text {ave }}$ & Rain $(\mathbf{m m})$ & SunHr & PET $(\mathbf{m m})$ \\
\hline Jan & 22.1 & 33.9 & 28.0 & 0.0 & 6.7 & 70.8 \\
Feb & 23.8 & 35.6 & 29.7 & 64.9 & 7.6 & 83.25 \\
Mar & 24.1 & 34.7 & 29.4 & 51.0 & 5.3 & 113.3 \\
April & 23.9 & 33.9 & 28.9 & 126.2 & 6.7 & 116.5 \\
May & 22.9 & 31.7 & 27.3 & 173.2 & 6.2 & 119.8 \\
June & 22.9 & 30.6 & 26.8 & 212.2 & 5.9 & 103.5 \\
July & 21.6 & 28.2 & 24.9 & 160.0 & 3.6 & 86.3 \\
August & 21.1 & 27.1 & 24.1 & 41.4 & 2.1 & 67.0 \\
Sept & 21.5 & 28.8 & 25.2 & 154.8 & 4.4 & 78.3 \\
October & 21.9 & 29.3 & 25.6 & 115.9 & 4.4 & 84.5 \\
\hline
\end{tabular}

Note. $\mathrm{T}_{\min }$ : Minimum temperature; $\mathrm{T}_{\max }$ : Maximum temperature; $\mathrm{T}_{\text {ave }}$ : Average temperature; Rain $(\mathrm{mm})$ : Amount of rainfall; SunHr: Sunshine hour; PET (mm): Potential evapotranspiration.

\subsection{Data Analysis}

All data obtained were subjected to Analysis of Variance (ANOVA) using the General Linear Model (GLM) procedures of SAS version 9.2 (SAS Institute, 2003). Means of the varieties for all the traits taken were separated using Least Significant Difference (LSD) at 0.05 level of probability. Furthermore, correlation among agronomic, grain yield and yield components traits were also carried out.

\section{Results}

Mean squares due to environments were significant $(\mathrm{P}=0.05)$ for ear diameter and highly significant $(\mathrm{P}=0.01)$ for emergence percent, ear number and weight, moisture content and grain yield per plot. There were no significant environmental effects for ear and plant heights, ear length and kernel row number (Table 3). Varietal effects were significant $(\mathrm{P}=0.05)$ for ear and plant heights and highly significant $(\mathrm{P}=0.01)$ for kernel row number (Table 3). This is also indication of differences in the varieties performance for plant and ear heights and kernel row number. Means squares associated with replication effect were only significant $(P=0.05)$ for ear number, and highly significant $(\mathrm{P}=0.01)$ for ear weight and grain yield. Environment $\times$ Variety interaction mean squares was only significant $(\mathrm{P}=0.05)$ for plant height and emergence percent (Table 3$)$. Generally, the coefficient of determination, $\mathrm{R}^{2}$ values of all the traits measured which ranged from $30 \%$ to $59 \%$ are lower compared to $\mathrm{R}^{2}$ value of $82 \%$ obtained for emergence percent. The coefficients of variability $(\mathrm{CVs})$ were low for kernel row number, moisture content and emergence percent $(7.43 \%, 8.00 \%$ and $9.14 \%)$ and rather high for ear number and grain yield $(40.55 \%$ and $35.34 \%)$ (Table 3 ). 
Table 3. Mean squares from the analysis of variance of agronomic traits, grain yield components and grain yield of drought tolerant maize varieties evaluated in two environments during the early cropping season of 2015

\begin{tabular}{|c|c|c|c|c|c|c|c|c|}
\hline Traits & $\begin{array}{l}\text { Env.(E) } \\
(\mathrm{Df}=1)\end{array}$ & $\begin{array}{l}\text { Var.(V) } \\
(D f .=9)\end{array}$ & $\begin{array}{l}\text { Rep } \\
(D f .=2)\end{array}$ & $\begin{array}{l}E \times V \\
(D f=9)\end{array}$ & $\begin{array}{l}\text { Error } \\
(D f=38)\end{array}$ & $\begin{array}{l}\text { Total } \\
(\mathrm{Df}=59)\end{array}$ & $\mathbf{R}^{2}$ & $\begin{array}{l}\text { CV } \\
(\%)\end{array}$ \\
\hline E\% & $1347.52 * *$ & $632.86^{* *}$ & 31.23 & $220.25^{* *}$ & 54.07 & 188.87 & 0.82 & 9.14 \\
\hline EHT & 74.44 & $564.59 *$ & 452.98 & 198.53 & 232.66 & 282.87 & 0.47 & 18.42 \\
\hline PHT & 214.52 & $718.27^{*}$ & 540.5 & $691.18^{*}$ & 258.52 & 403.46 & 0.59 & 10.53 \\
\hline ENO & $312.82 * *$ & 59.46 & $147.12 * *$ & 14.41 & 28.45 & 39.88 & 0.54 & 42.61 \\
\hline EWT & $3.41 * *$ & 0.18 & $1.19 * *$ & 0.13 & 0.22 & 0.29 & 0.51 & 36.48 \\
\hline MC & $26.27 * *$ & 4.14 & 3.65 & 4.58 & 3.27 & 4.01 & 0.47 & 8.66 \\
\hline ED & $1.31 *$ & 0.13 & 0.67 & 0.18 & 0.32 & 0.3 & 0.31 & 13.84 \\
\hline EL & 4.52 & 3.55 & 1.35 & 2.94 & 1.79 & 2.27 & 0.49 & 10.04 \\
\hline KRN & 2.43 & $2.73 * *$ & 2.17 & 0.76 & 0.91 & 1.24 & 0.52 & 7.55 \\
\hline YLD & $12.31 * *$ & 0.79 & $4.58 * *$ & 0.51 & 0.87 & 1.12 & 0.50 & 36.80 \\
\hline
\end{tabular}

Note. E\%: Emergence percent; EHT: Ear Height; PHT: Plant Height; ENO: Ear Number; EWT: Ear Weight; MC: Moisture Content; ED: Ear Diameter; EL: Ear Length; KRN: Kernel Row Number; YLD: Yield; Env.: Environment; Var.: Variety; $\mathrm{R}^{2}$ : Coefficient of determination; CV: Coefficient of variability.

Table 4 showed environmental means of yield and yield components of drought tolerant maize varieties evaluated during drought and rain-fed conditions of the early cropping season of 2015. There were significant differences among the two environments for emergence percent, ear number, ear weight $(\mathrm{kg})$, moisture content $(\%)$, ear diameter $(\mathrm{cm})$ and grain yield (tons/ha). The yield components; ear number, ear weight, moisture content and ear diameter of the drought tolerant maize varieties are higher under the rain-fed condition when compared to drought condition. This is indication of the difference in the climatic conditions of the two environments; drought and rain-fed conditions.

Table 4. Environmental means of yield components of drought tolerant maize varieties evaluated during the early cropping season of 2015 at the Teaching and Research Farm, Obafemi Awolowo University (OAU), Ile-Ife

\begin{tabular}{lllllll}
\hline Environments & E\% & ENO & EWT & MC & ED & YLD \\
\hline March 26, 2015 (Drought) & 75.69 & 10.23 & 1.04 & 20.21 & 3.93 & 2.08 \\
June 30, 2015 (Rain-fed) & 82.17 & 14.80 & 1.52 & 21.53 & 4.23 & 2.98 \\
LSD $_{\mathbf{0 . 0 5}}$ & 4.81 & 2.64 & 0.23 & 0.97 & 0.28 & 0.46 \\
\hline
\end{tabular}

Obatanpa recorded significantly lowest emergence percent of $57.74 \%$ compared to other varieties (from $74.75 \%$ to $90.24 \%$ ). Obatanpa and 2004 TZE-WDT STR $C_{4}$ recorded significantly higher ear heights $(104.22 \mathrm{~cm}$ and $87.22 \mathrm{~cm}$ ) compared to other varieties (from $68.05 \mathrm{~cm}$ to $85.22 \mathrm{~cm}$ ); while EVDT-W $2000 \mathrm{STR} \mathrm{C}_{0}$ and DT-Y STR Synthetic recorded lower plant heights values $(130.65 \mathrm{~cm}$ and $136.52 \mathrm{~cm})$ compared to the other varieties (from $147.63 \mathrm{~cm}-162.18 \mathrm{~cm}$ ). EVDT-W $2000 \mathrm{STR} \mathrm{C}_{0}$ and Obatanpa recorded higher mean value of kernel row number 14.20 and 13.20 compared to other varieties with lower kernel row number values (from 11.87 to 12.87 ) (Table 5). 
Table 5. Varietal means of plant and ear heights (PHT, EHT) and kernel row number (KRN) of drought tolerant maize varieties evaluated at the Teaching and Research Farm, Obafemi Awolowo University, Ile-Ife in the two environments during the early cropping seasons of 2015

\begin{tabular}{lllll}
\hline Varieties & E\% & EHT & PHT & KRN \\
\hline 2004TZE-WDTSTRC $_{4}$ & 81.48 & 87.20 & 158.72 & 12.87 \\
EVDT-W2000STRC $_{0}$ & 76.68 & 71.44 & 130.65 & 14.20 \\
2013DTESTR-YSyn $_{\text {DT-YSTRSynthetic }}$ & 89.73 & 83.50 & 158.12 & 12.73 \\
2009TZE-WDTSTR & 76.35 & 68.05 & 136.52 & 12.56 \\
2008DTMA-YSTR & 90.15 & 82.03 & 147.63 & 11.93 \\
2012TZE-WDTC $_{4}$ STRC $_{5}$ & 89.65 & 79.23 & 160.08 & 12.40 \\
2014TZE-WDT STR $_{2011 \text { TZE-Y DT STR }}$ & 90.24 & 85.22 & 155.28 & 12.63 \\
Obatanpa (Local Check) $_{\text {LSD }_{\mathbf{0 . 0 5}}}^{74.75}$ & 82.92 & 162.18 & 11.87 \\
\hline
\end{tabular}

Generally, the emergence percent of the varieties were higher under the rain-fed condition compared to drought condition. However 2011TZE-YDTSTR which was among the varieties with the lowest emergence percent (6.791\%) under drought was observed to be among the varieties with highest emergence percent $(93.27 \%)$ under rain-fed condition. Obatanpa, the local check which was among the varieties with the lowest plant heights $(133.05 \mathrm{~cm})$ during drought condition recorded the highest plant height $(190.20 \mathrm{~cm})$ during rain-fed condition (Table 6). The relative performance of most of the drought tolerant maize varieties under drought and rain-fed conditions are similar for plant height. For instance, the plant height of 2009TZE-WDTSTR was observed to be $147.73 \mathrm{~cm}$ under drought and $147.53 \mathrm{~cm}$ under rain-fed condition (Table 6).

Table 6. Varietal means of emergence $\%$ and plant height $(\mathrm{cm})$ of ten maize varieties evaluated under drought and rain-fed conditions during the early cropping season of 2015

\begin{tabular}{|c|c|c|c|c|}
\hline \multirow{2}{*}{ Varieties } & \multicolumn{2}{|c|}{ March 26, 2015 (Drought) } & \multicolumn{2}{|c|}{ June 30, 2015 (Rain-fed) } \\
\hline & $\mathbf{E \%}$ & $\begin{array}{l}\text { PHT } \\
\end{array}$ & $\mathrm{E} \%$ & PHT \\
\hline 2004TZE-WDTSTRC 4 & 76.94 & 158.90 & 86.03 & 158.53 \\
\hline EVDT-W2000STRC $_{0}$ & 68.86 & 119.30 & 84.51 & 142.00 \\
\hline 2013DTESTR-YSyn & 84.01 & 165.17 & 95.46 & 151.07 \\
\hline DT-YSTRSynthetic & 66.84 & 135.83 & 85.86 & 137.20 \\
\hline 2009TZE-WDTSTR & 86.53 & 147.73 & 93.77 & 147.53 \\
\hline 2008DTMA-YSTR & 86.36 & 167.83 & 92.93 & 152.33 \\
\hline 2012TZE-WDTC $_{4}$ STRC $_{5}$ & 86.03 & 158.50 & 94.44 & 152.07 \\
\hline 2014TZE-WDTSTR & 74.07 & 164.50 & 75.42 & 159.87 \\
\hline 2011TZE-YDTSTR & 61.79 & 156.50 & 93.27 & 154.33 \\
\hline Obatanpa (Local Check) & 65.49 & 133.05 & 50.00 & 190.20 \\
\hline $\mathbf{L S D}_{0.05}$ & 14.65 & 30.70 & 5.91 & 21.74 \\
\hline
\end{tabular}

The grain yield performance of the drought tolerant maize varieties evaluated under rain-fed condition of this study are higher compared to their yield performance under drought condition (Table 7). Based on $\mathrm{LSD}_{0.05}$, all the varieties evaluated under drought condition produced grain yield (1.79 tons/ha- 2.75 tons/ha) which are not significantly different from each other except EVDT-W2000STRC $\mathrm{S}_{0}$ which had significantly lower grain yield (1.10 tons/ha) while under rain-fed condition, the yield performance of all the varieties (2.44 tons/ha-3.69 tons/ha) were not significantly different from each other (Table 7). 
Table 7. Varietal means of grain yield (tons/ha) of ten maize varieties evaluated under drought and rain-fed conditions during the early cropping season of 2015

\begin{tabular}{|c|c|c|}
\hline Varieties & March 26, 2015 (Drought) & June 30, 2015 (Rain-fed) \\
\hline 2004 TZE-WDTSTRC $_{4}$ & 2.44 & 3.42 \\
\hline EVDT-W 2000 STRC $_{0}$ & 1.10 & 2.60 \\
\hline 2013 DTESTR-YSyn & 2.21 & 2.89 \\
\hline DT-YSTR Synthetic & 1.79 & 3.16 \\
\hline 2009 TZE-WDTSTR & 2.75 & 3.69 \\
\hline 2008 DTMA-YSTR & 2.43 & 2.59 \\
\hline 2012 TZE-WDTC $_{4}$ STRC $_{5}$ & 2.44 & 2.73 \\
\hline 2014 TZE-WDTSTR & 2.20 & 2.45 \\
\hline 2011 TZE-YDTSTR & 2.07 & 3.01 \\
\hline Obatanpa (Local Check) & 1.36 & 3.31 \\
\hline $\mathbf{L S D}_{0.05}$ & 1.42 & 1.80 \\
\hline
\end{tabular}

Correlation coefficients among emergence, vegetative, grain yield and yield components under the marginal rainfall condition of the early part of the early cropping season depicting drought condition and rain-fed condition of 2015 are presented in Tables 8 and 9, respectively. All the yield components except ear height, moisture content and ear length had a strong positive relationship with grain yield under drought while under rain-fed condition only ear number and ear weight are significantly correlated with yield. Under drought condition, ear number was observed to be positively correlated with emergence percent $(r=0.66, P \leq 0.05)$. Ear weight and grain yield were also observed to be highly positively correlated with emergence percent $(\mathrm{r}=0.74, \mathrm{P}$ $\leq 0.01)$ (Table 8). Ear number and length were also significantly correlated with plant height $(\mathrm{r}=0.64,0.75, \mathrm{P} \leq$ $0.05)$. Ear weight, diameter and grain yield were highly positively correlated with plant height $(\mathrm{r}=-0.79,0.90$, $0.80, \mathrm{P} \leq 0.01)$ while kernel row number was negatively correlated with plant height $(\mathrm{r}=0.63, \mathrm{P} \leq 0.05)$ under drought condition of this study (Table 8). Highly positive correlation was observed in ear weight, ear diameter, and grain yield with ear number $(\mathrm{r}=0.92,0.79,0.93, \mathrm{P} \leq 0.01)$ while a negative significant correlation was observed between kernel row number and ear number $(\mathrm{r}=-0.68, \mathrm{P}=0.05)$ (Table 8). Ear diameter and grain yield are highly correlated with ear weight $(\mathrm{r}=0.91,0.99, \mathrm{P} \leq 0.01)$ under the drought condition of this study, (Table 8). Positive correlation was observed between kernel row number and moisture content $(\mathrm{r}=0.73, \mathrm{P} \leq 0.05)$ of the maize varieties used in this study under drought (Table 8). Ear length, kernel row number $(r=0.73,-0.71$, $\mathrm{P} \leq 0.05)$ and grain yield $(\mathrm{r}=0.92, \mathrm{P} \leq 0.01)$ has significant positive and negative correlation with ear diameter (Table 8). A negative significant correlation was observed between grain yield and kernel row number $(r=-0.64$, $\mathrm{P} \leq 0.05$ ) under the drought condition of this study (Table 8).

Under rain-fed condition of this study, plant height, moisture content $(r=-0.82,-0.92, P \leq 0.01)$ and ear length(r $=0.66, \mathrm{P} \leq 0.05)$ are negatively correlated with emergence percent (Table 9$)$. Only plant height is positively correlated with ear height $(\mathrm{r}=0.68, \mathrm{P} \leq 0.05)$. Positive correlations were observed in moisture content $(\mathrm{r}=0.76$, $\mathrm{P} \leq 0.01)$ and ear length $(\mathrm{r}=0.72, \mathrm{P} \leq 0.05)$ with plant height. Ear weight and grain yield are positively correlated with ear number $(\mathrm{r}=0.63,0.69, \mathrm{P} \leq 0.05)$. Grain yield was highly positively correlated with ear weight $(\mathrm{r}=0.99, \mathrm{P} \leq 0.01)$. A positive correlation was observed between ear length and moisture content $(\mathrm{r}=$ $0.68, \mathrm{P} \leq 0.05)($ Table 9). 
Table 8. Pearson correlation among emergence, vegetative, grain yield and yield components of 10 maize varieties evaluated during the early part (March 29) (drought) of the early cropping season of 2015.

\begin{tabular}{llllllllll}
\hline & E\% & EHT & PHT & ENO & EWT & MC & ED & EL & KRN \\
\hline EHT & -0.05 & - & & & & & & & \\
PHT & 0.55 & 0.18 & - & & & & & & \\
ENO & $0.66^{*}$ & -0.01 & $0.64^{*}$ & - & & & & & \\
EWT & $0.74^{* *}$ & -0.07 & $0.79^{* *}$ & $0.92^{* *}$ & - & & & & \\
MC & -0.33 & -0.62 & -0.59 & -0.58 & -0.50 & - & & & \\
ED & 0.57 & 0.08 & $0.90^{* *}$ & $0.79^{* *}$ & $0.91^{* *}$ & -0.55 & - & & \\
EL & 0.40 & -0.06 & $0.71^{*}$ & 0.31 & 0.60 & -0.39 & $0.73^{*}$ & - & - \\
KRN & -0.05 & -0.25 & $-0.63^{*}$ & $-0.68^{*}$ & -0.61 & $0.73 *$ & $-0.71^{*}$ & -0.41 & - \\
YLD & $0.74^{* *}$ & -0.03 & $0.80^{* *}$ & $0.93^{* *}$ & $0.99^{* *}$ & -0.55 & $0.92^{* *}$ & 0.61 & $-0.64 *$ \\
\hline
\end{tabular}

Table 9. Pearson correlation among emergence, vegetative, grain yield and yield components of 10 maize varieties evaluated during the early (June 30) (rain-fed) cropping season of 2015

\begin{tabular}{llllllllll}
\hline & E\% & EHT & PHT & ENO & EWT & MC & ED & EL & KRN \\
\hline EHT & -0.42 & - & & & & & & & \\
PHT & $-0.82^{* *}$ & $0.68^{*}$ & - & & & & & & \\
ENO & 0.54 & 0.05 & -0.47 & - & & & & & \\
EWT & -0.20 & 0.54 & 0.26 & $0.63^{*}$ & - & & & & \\
MC & $-0.92^{* *}$ & 0.47 & $0.76^{* *}$ & -0.46 & 0.12 & - & & & \\
ED & -0.09 & -0.04 & -0.16 & -0.28 & -0.20 & 0.12 & - & & - \\
EL & $-0.66^{*}$ & 0.41 & $0.72^{*}$ & -0.35 & 0.06 & $0.68^{*}$ & -0.33 & - & \\
KRN & -0.35 & 0.06 & 0.27 & -0.25 & 0.13 & 0.24 & 0.18 & -0.35 & - \\
YLD & -0.01 & 0.49 & 0.17 & $0.69^{*}$ & $0.99^{* *}$ & 0.02 & -0.20 & 0.02 & 0.10 \\
\hline
\end{tabular}

\section{Discussion}

The results of significant differences observed among the two planting environments (Drought and rain-fed conditions) in 2015 early cropping season for most of the traits taken were expected because the planting dates received different amounts of temperature, rainfall, sunshine hour and potential evapotranspiration (Table 1). Those factors which are the important climatic factors determining the performance of maize in the rainforest zone of Nigeria as reported by Oluwaranti et al. (2008).

There were no significant differences among the varieties for most of the yield and yield components traits during the rain-fed condition in this study since the amount of rainfall and other climatic conditions are sufficient for the normal growth of these varieties of maize. Although there were varietal significant difference among the varieties for emergence percent, ear and plant height and kernel row number, this might have been due to land gradients of the experimental station.

Highly significant differences among replications for ear number, ear weight and yield should not be too surprising because soil texture could vary within experimental field. Seeds planted on coarse and loose soil emerged faster than those planted in fine and sticky soil. This emergence problem affected most traits under the drought condition as observed by Fakorede et al. (2004). Highly significant interaction of planting environments by varieties that were observed for emergence percentage and plant height is an indication of the differences in micro environment of the two planting dates and the genetic make-up of the maize varieties evaluated in this study including the local checks which has not been improved for drought tolerance. The height of Obatanpa, the local check was shorter under drought condition when compared to rain-fed condition.

The higher grain yield obtained under the rain-fed condition of this study is not too surprising since the planting was done in June, an early cropping season planting and this month was among the months with the highest amount of rainfall for 2015 as shown in Table 1. This is in corroboration with the findings of Fakorede and Akinyemiju (2003) which noted that rainfall is the primary environmental factor determining when to plant maize in the rainforest agro-ecology. Emphasis is usually laid on early season maize production in Nigeria 
because the yield is higher and the weather, especially rainfall, is more favourable as noted by Oluwaranti et al. 2008.

The result of the yield components having positive relationship with the grain yield under drought condition are expected as reported in previous studies. Bolanos and Edmeades (1996) reported highly significant and positive correlation $\left(\mathrm{r}=0.8^{* *}\right)$ for kernel number with grain yield and Gemenet et al. (2010) reported highly significant positive correlation $\left(\mathrm{r}=0.91^{* *}\right)$ for kernel number with grain yield and relatively high correlations $(\mathrm{r}=0.54)$ of ear number with grain yield. This is indication of strong dependency of grain yield under drought stress on these yield components. These results also confirm the genetic basis of the phenotypic findings by Andrade et al. (1999) and Xiao et al. (2005) that ear number, ear weight, kernel row number directly influence the grain yield; grain yield in turn is more correlated with ear weight than any other yield components thereby demonstrating the fact that ear weight is the most important yield component for maize than other grain yield components in this study. This ear weight trait has the potential to be used as selection trait to render drought tolerance to maize.

In conclusion, the drought tolerant maize varieties evaluated in this study demonstrated good performance under drought, although with better grain yield under rain-fed condition. There are no varietal differences among eight out of the nine maze varieties for yield under drought except EVDT-W 2000 STR $\mathrm{C}_{0}$ that need further improvement for drought tolerance. Ear weight was identified as a reliable trait for selecting for drought tolerance in maize.

\section{Acknowledgements}

We express our sincere appreciation to Maize Breeding Program of the International Institute of Tropical Agriculture (IITA), Ibadan Nigeria for the provision of seeds of maize varieties used for this study.

\section{References}

Andrade, F. H., Vega, C., Uhart, S., Cirilo, A., Cantarero, M., \& Valentinuz, O. (1999). Kernel number determination in maize. Crop Science, 39, 453-459. http://dx.doi.org/10.2135/cropsci1999.0011183X00390 00200026x

Ashley, J. (1999). Food crop and drought. In. CTA Macmillan Ltd. London, p. 13.

Badu-Apraku, B., Menkir, A., Ajala, S. O., Akinwale, R. O., Oyekunle, M., \& Obeng-Antwi, K. (2010). Performance of tropical early-maturing maize cultivars in multiple stress environments. Can. J. Plant Sci., 90, 831-852. http://dx.doi.org/10.4141/cjps10059

Bolanos, J., \&. Edmeades, G. O. (1996). The importance of the anthesis-silkinginteval in breeding for drought tolerance in tropical maize. Field Crops Research, 48, 65-80. http://dx.doi.org/10.1016/0378-4290(96)00036-6

Demirevska, K., Simova-Stoilova, L., Fedina, I., Georgieva, K., \& Kunert, K. (2009). Response of Oryzacystatin I Transformed Tobacco Plants to Drought, Heat and Light Stress. Journal of Agronomy and Crop Science, 196(2), 90-99. http://dx.doi.org/10.1111/j.1439-037X.2009.00396

Edemeades, G. O., Bolaños, J., \& Chapman, S. C. (1997). Value of secondary traits in selecting for drought tolerance in tropical maize. In G. O. Edemeades, M. Bäzinger, H. R. Mickelson, C. B. Pena-Valdivia (Eds.), Developing drought- and low- $N$ tolerant maize: Proceedings of a symposium, March 25-29, 1996. CIMMYT, EI Batan. Mexico, D.F.

Edmeades, G. O. (2008). Drought Tolerance in Maize: An Emerging Reality. In C. James (Ed.), Global Status of Commercialized Biotech/GM Crops: 2008. ISAAA Brief No. 39. ISAAA: Ithaca, NY.

Edmeades, G. O., Banziger, M., Schussler, J. R., \& Campos, H. (2004). Improving abiotic stress tolerance in maize: a random or planned process. Proceedings of the Arnel $R$ Hallauer International Symposium on Plant Breeding, Mexico City, August 17-22, 2003, Iowa State University Press.

Fakorede, M. A. B., \& Akinyemiju, O. A. (2003). Climatic change: Effects on maize production in a tropical rainforest location. In B. Badu-Apraku, M. A. B. Fakorede, M. Ouedraogo, \& R. J. Carsky \& A. Menkir (Eds.), Maize Revolution in West and Central Africa (pp. 272-282). Proceedings of Fourth Biennial West and Central Africa Regional Maize Workshop, May 14-18, 2001, IITA Cotonou, Benin Republic.

Fakorede, M. A. B., Saka, A., \& Ajayi, S. A. (2004). Drought probability during the cropping season in a rainforest location: Implication for maize production. Paper presented at the Annual Conference of the Nigeria Society for Environmental Management, Obafemi Awolowo University, Ile-Ife, May 13-14, 2004. 
FAOSTAT. (2012). Food and Agricultural Organization of the United Nations (FAO), FAO Statistical Database, 2012. Retrieved November 15, 2014, from http://faostat.fao.org

Gemenet, D. C., Wachira, F. N., Pathak, R. S., \& Munyiri, S. W. (2010). Identification of molecular markers linked to drought tolerance using bulked segregant analysis in Kenyan maize (Zea mays L.) landraces. Journal of Animal \& Plant Sciences, 9(1), 1122- 1134.

Kim, S. K. (1997). Achievements, challenges and future direction of hybrid maize research and prodycution in West and Central Africa. In B. Badu-Apraku, M. O. Akoroda, M. Ouderago \& F. M. Quin (Eds.), Contributing to food self-sufficiency (pp. 42-81). Proc. of a Regional Maize Workshop May 29-June 2, 1995, IITA, Cotonou, Benin Republic.

Milander, J. J. (2015). Maize Yield and Components as Influenced by Environment and Agronomic Management (Master's Thesis, University of Nebraska-Lincoln, US). Retrieved from http://digitalcommons.unl.edu/agronhortdiss/86

Oluwaranti, A., Fakorede, M. A. B., \& Badu-Apraku, B. (2008). Grain yield of maize varieties of different maturity groups under marginal rainfall conditions. Journal of Agricultural Sciences, 53(3), $183-191$. http://dx.doi.org/10.2298/jas0803183o

SAS Institute. (2003). SAS/STAT User'guide (Version 9.2). SAS Institute, Inc., Cary, NC, USA.

Shao, H. B., Chu, L. Y., Jaleel, C. A., Manivannan, P., Panneerselvam, R., \& Shao, M. A. (2009). Understanding water deficit stress-induced changes in the basic metabolism of higher plants-biotechnologically and sustainably improving agriculture and the ecoenvironment in arid regions of the globe. Crit. Rev. Biotechnol., 29, 131-151. http://dx.doi.org/10.1080/07388550902869792

Xiao, Y. N., Li, X. H., George, M. L., Li, M. S., Zhang, S. H., \& Zheng, Y. L. (2005). Quantitative Trait Locus Analysis of Drought Tolerance and Yield in Maize in China. Plant Molecular Biology, 23, $155-165$. http://dx.doi.org/10.1007/BF02772706

\section{Copyrights}

Copyright for this article is retained by the author(s), with first publication rights granted to the journal.

This is an open-access article distributed under the terms and conditions of the Creative Commons Attribution license (http://creativecommons.org/licenses/by/3.0/). 